\title{
Sediment Transport in Kulim River, Kedah, Malaysia
}

\author{
Chun Kiat, Chang and Aminuddin, Ab. Ghani \\ Universiti Sains Malaysia \\ Malaysia
}

\section{Introduction}

Rivers are dynamic by nature; they adjust their characteristics in response to any change in the environment. These environmental changes may occur naturally, as in the case of climatic variation or changes in vegetative cover, or may be a result of human activities. Human factors influence channel changes, both directly by engineering projects including channelization, dredging, snag removals, dam construction and bridge construction, and indirectly through altering floodplain landuse such that erosion is more likely to occur during flood events more likely to occur during flood events (Ab. Ghani et al., 2010). These changes to river hydrology and sedimentation will in turn modify the channel morphology, which include changes to channel cross section, stability and capacity. Otherwise, hazard flood increases with the sedimentation and damages exceeded with muddy water. Consequently, it is necessary to study river channel behaviour and evaluate the river channel stability for its natural state and response to human modification due to the existing and future developments.

\section{Study site}

Kulim River catchment (Figure 1) is located in the southern part of the state of Kedah and in the northwestern corner of Peninsular Malaysia. Kulim River is a natural stream in Kedah state, Malaysia. Kulim River drains $130 \mathrm{~km}^{2}$ of the surface area of southern part of the state of Kedah, is in the northwestern corner of Peninsular Malaysia. Kulim River emanates from the western slopes on Gunung Bangsu Range and flows in a north-westerly direction. The river slopes are steep and channel elevations drop from 500 meter to 20 meter above mean sea level (AMSL) over a distance of 9 kilometer. The central area of the catchment is undulating with elevation ranging from 100 meter down to 18 meter above mean sea level. The study area has a tropical climate influenced by the movement of Inter-Tropical Convergence Zone. Its passage over the area results in two wet periods during the year which occur from April to May and from September to November. There is a transitional period of moderate rainfall during June to August and dry during December to March. Rainfall is generally convective and increase from around $2000 \mathrm{~mm}$ a year at the downstream to over $3200 \mathrm{~mm}$ a year on the mountainous area.

The Kulim River has experienced severe environmental damages, mostly related to significant erosion and sedimentation. Anthropogenic activities and natural events cause 
changes in river morphology and stability of Kulim River. The human activity include the development to the year 2010 of Kulim district based on the Kulim Structure Plan, 1990-2010 (MDK, 1993), rapid urbanization at Kulim River catchment especially construction for housing state, the on-going $145 \mathrm{~km}^{2}$ Malaysia's first and fully integrated Kulim Hi-Tech Industrial Park and river sand mining activities which may maximize the disturbance to river equilibrium and environment. Frequent flood occurrences in Kulim River catchment have significantly affected the community because of extensive damage in built up and agriculture areas especially the flood event in October 2003, which is an event slightly lower than the 100year ARI based on the frequency analysis. Finally, these changes to the river hydrology and sedimentation will in turn alter the channel morphology, which can include changes to channel cross section, stability and capacity (Chang et al., 2005). The study reach covers about $14.4 \mathrm{~km}$ of Kulim River, from the upstream ( $\mathrm{CH} 14390)$ to the state boundary between Kedah and Penang (CH 1900) and further downstream at the Ara Kuda gauging station (CH 0).

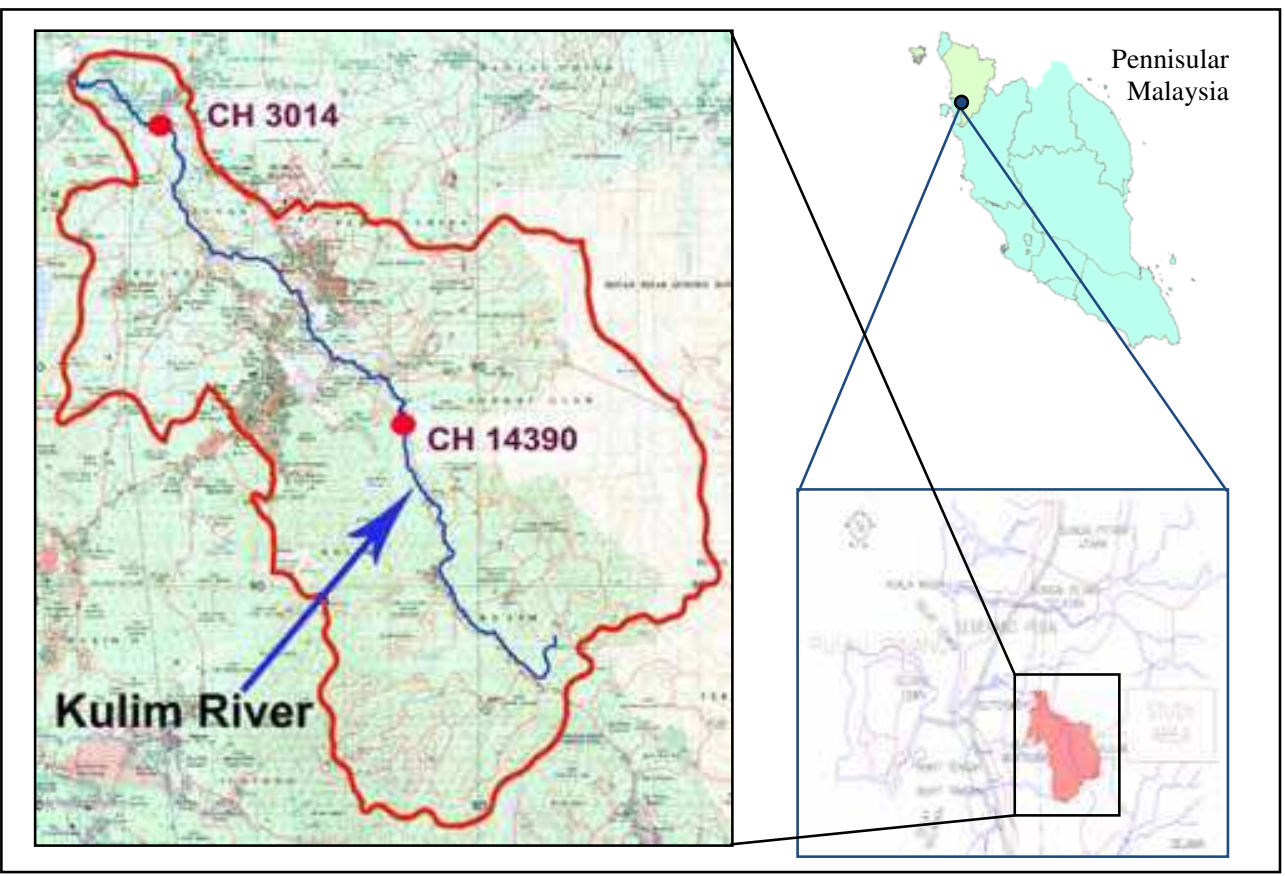

Fig. 1. Delineated Kulim River Catchment and Study Reach

\section{Flood frequency analysis}

The Kulim River benefited from 46-year period (1960-2005) of daily discharge measurements at Ara Kuda streamflow station, which include two major floods have occurred in 2001 and 2003 within the period. The annual peak discharges ranked in Table 1 indicate that the ten largest floods have been measured since 1961. This can be considered that the discharge of $92.90 \mathrm{~m}^{3 / \mathrm{s}}$ measured in 5 October 2003 is the highest during that period of record. 


\begin{tabular}{|c|c|c|c|}
\hline Rank & Discharge, $\left.\mathbf{Q} \mathbf{~} \mathbf{m}^{\mathbf{3}} \mathbf{s}\right)$ & Year & Date \\
\hline 1 & 92.90 & 2003 & 05-Oct \\
\hline 2 & 89.90 & 2001 & 22-Jan \\
\hline 3 & 67.90 & 1998 & 16-Nov \\
\hline 4 & 65.00 & 2000 & $22-$ Sep \\
\hline 5 & 62.30 & 1963 & 13-Nov \\
\hline 6 & 61.20 & 1999 & $05-$ Sep \\
\hline 7 & 58.50 & 2004 & $23-$ Sep \\
\hline 8 & 57.90 & 1962 & 21-Oct \\
\hline 9 & 56.90 & 1964 & 26-Sep \\
\hline 10 & 55.10 & 1987 & 09-Nov \\
\hline
\end{tabular}

Table 1. Flood Ranking for Kulim River at Ara Kuda

A flood frequency analysis was carried out for the 42-year period of streamflow data using Gumbel Extremal Type I. It was found that the result shows the better agreement to the measured streamflow data (Figure 2). The flood frequency analysis provided by the present study is also given in Table 2. It is therefore concluded that the 2003 flood discharge of 92.90 $\mathrm{m}^{3 /} \mathrm{s}$ is slightly lower than the 100 -year peak discharge.

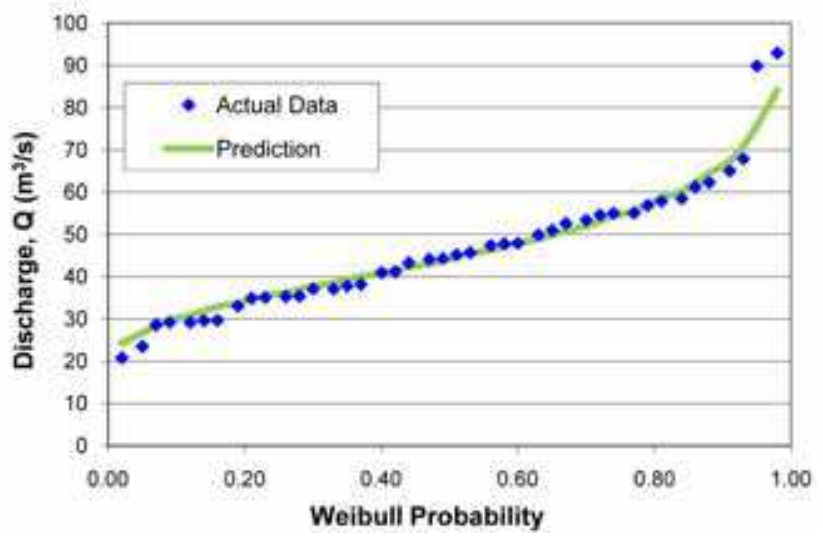

Fig. 2. Flood Frequency Analyses Using Gumbel Extremal Type I Distribution

\begin{tabular}{|c|c|}
\hline Return Period & Discharge $\left(\mathrm{m}^{3 / \mathrm{s}}\right)$ \\
\hline 200 & 102.27 \\
\hline 100 & 94.08 \\
\hline 50 & 85.86 \\
\hline 25 & 77.58 \\
\hline 10 & 66.42 \\
\hline 5 & 57.59 \\
\hline 3 & 50.58 \\
\hline 2 & 44.25 \\
\hline
\end{tabular}

Table 2. Summary of Flood Frequency Analyses using Gumbel Extremal Type I 


\section{Sediment data collection and analysis}

\subsection{Field measurement}

River surveys, flow measurement and field data collection provide the basic physical information such as sediment characteristics, discharge, water surface slope; which is needed for the planning and design of river engineering. In addition to the data needed for sediment transport studies, use of a sediment transport model also requires field data such as channel configuration before and after the changes, a flow record and sediment characteristics, which are generally used for test and calibration of a model. Field measurements were obtained at the selected cross sections (CH 14390 and $\mathrm{CH}$ 3014) from October 2004 to November 2006 along Kulim River by using Hydrological Procedure (DID, 1976; DID, 1977) and recent manuals (Yuqian, 1989; USACE, 1995; Edwards \& Glysson, 1999; Lagasse et al., 2001; Richardson et al., 2001). The data collection includes flow discharge (Q), suspended load $\left(\mathrm{T}_{\mathrm{s}}\right)$, bed load $\left(\mathrm{T}_{\mathrm{b}}\right)$ and water surface slope $\left(\mathrm{S}_{\mathrm{o}}\right)$. The water-surface slopes of the study reaches were determined by taking measurements of water levels over a distance of $200 \mathrm{~m}$ where the cross section was located (FISRWG, 2001). Besides that, bed elevation, water surface and thalweg (the minimum bed elevation for a cross section) measurement were also carried out at the selected cross sections. Details and examples of the measurement methodology for rivers in Malaysia can be found in Ab. Ghani et al. (2003) and DID (2009).

In this study, the water-surface slopes were found to be mild, where the average slope, $\mathrm{S}_{0}$ for $\mathrm{CH} 14390$ and $\mathrm{CH} 3014$ is $0.001 \mathrm{~m} / \mathrm{m}$. Bed material samples were also collected at the selected cross sections including bank samples. This data were analyzed to determine the distributions of the mean sediment size or $d_{50}$ and used to characterize the physical characteristics of the sediment responsible for sediment transport, which determines the river response in terms of erosion and deposition. Low sediment transport rate for Kulim River occurred during the field measurements. The mean sediment sizes show that Kulim River is sand-bed streams where $d_{50}$ ranges from 1.00 to $2.40 \mathrm{~mm}$.

A summary with ranges for hydraulics and sediment data collection is shown in Table 3 (Chang et al., 2008). The surveyed cross sections for the Kulim River show that it is a single

\begin{tabular}{|l|c|c|}
\hline Study Site & CH 14390 & CH 3014 \\
\hline No. of Sample & 10 & 12 \\
\hline Discharge, $\mathrm{Q}\left(\mathrm{m}^{3 / \mathrm{s})}\right.$ & $0.73-3.14$ & $3.73-9.98$ \\
\hline Bankfull width, TW $(\mathrm{m})$ & 25.0 & 50.0 \\
\hline Water surface width, B $(\mathrm{m})$ & $9.0-13.0$ & $13.0-19.0$ \\
\hline Flow depth, $\mathrm{y}_{\mathrm{o}}(\mathrm{m})$ & $0.20-0.54$ & $0.36-0.58$ \\
\hline Hydraulic radius, $\mathrm{R}(\mathrm{m})$ & $0.23-0.57$ & $0.40-0.63$ \\
\hline Water surface slope, $\mathrm{S}_{\mathrm{o}}$ & 0.001 & 0.001 \\
\hline Mean sediment size, $\mathrm{d}_{50}(\mathrm{~mm})$ & $1.00-2.40$ & $1.10-2.00$ \\
\hline Manning $n$ & $0.029-0.072$ & $0.024-0.037$ \\
\hline $\mathrm{B} / \mathrm{y}_{\mathrm{o}}$ & $23.4-44.8$ & $26.0-52.5$ \\
\hline $\mathrm{y}_{\mathrm{o}} / \mathrm{d}_{50}$ & $126.9-369.01$ & $240.0-550.9$ \\
\hline $\mathrm{R} / \mathrm{d}_{50}$ & $141.4-406.6$ & $266.5-570.9$ \\
\hline Bed load, $\mathrm{T}_{\mathrm{b}}(\mathrm{kg} / \mathrm{s})$ & $0.06-0.33$ & $0.11-0.36$ \\
\hline Suspended load, $\mathrm{T}_{\mathrm{s}}(\mathrm{kg} / \mathrm{s})$ & $0.02-0.27$ & $0.03-1.21$ \\
\hline Total load, $\mathrm{T}_{\mathrm{j}}(\mathrm{kg} / \mathrm{s})$ & $0.09-0.56$ & $0.27-1.35$ \\
\hline
\end{tabular}

Table 3. Range of Field Data for Kulim River Catchment (Chang et al., 2008) 


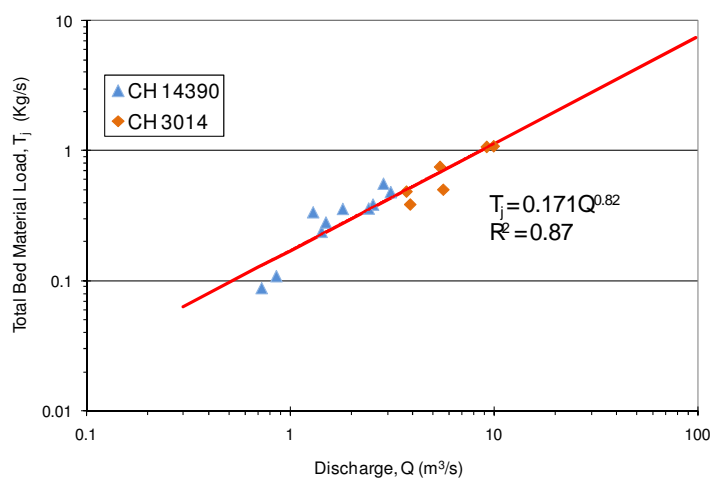

Fig. 3. Sediment Rating Curve along Kulim River

thread channel with the bankfull width ranging between 25 and $50 \mathrm{~m}$, and aspect ratio $\left(\mathrm{B} / \mathrm{y}_{\mathrm{o}}\right.$ ) was between 23 and 53 indicating that it is a moderate-size channel. The total bed material load $\left(\mathrm{T}_{\mathrm{j}}\right)$ is composed of the suspended load and bed load, representing the ability of the river to replenish the sediment and it must be specified for sediment transport, scour and deposition analysis. The measured total bed material load rating curves for these two sites at the Kulim River are illustrated in Figure 3. A mild curve is obtained for Kulim River indicating that a longer time is required for the replenishment before it is viable for sand extraction purpose. Therefore it is recommended that deposition should be allowed to occur first after a major flood before any river sand mining activity is allowed between these two sites. Based on the Table 1 and Figure 3, it is estimated that the 2003 flood with a discharge of $93 \mathrm{~m}^{3 / \mathrm{s}}$ will transport $7 \mathrm{~kg} / \mathrm{s}$ of sand during the flood.

\subsection{Channel morphology}

Water and sediment transport through the Kulim River increase with time due to the reduction of river capacity that resulted from reclamation and sedimentation along the river. River bank erosion, river bed degradation, river buffer zone encroachment and deterioration of river water quality cause a serious and regular hazard in urban settlements at Kulim town. The powerful water currents wear away at the edges of these settlements during the wet periods and sometimes entire settlements established near the bank are washed away. Figure 4 shows the channel planform modification along Kulim River due to an event slightly lower than the 100-year ARI flood during October 2003 at two urbanized areas of Kulim town and its surrounding areas. The main and most urbanized area of Kulim River pass the Kulim town and its surrounding. The channel widening can be observed in many locations along the Kulim River such as $\mathrm{CH}$ 10000, $\mathrm{CH} 12000$ and $\mathrm{CH}$ 13500. The depositional areas are mainly located at the outer banks of meanders, while the erosion areas are at the opposite banks. These changes in channel river planform may cause extensive damages and inconvenience to the community (Sirdari, 2009).

Field measurements results including bed elevation, thalweg and water surface were carried out at several cross sections were compared to the river survey geometry data in September 1991. However, the comparison between cross sections provided by Department of Irrigation and Drainage (DID) and field measurement after October 2003 flood shows that there has been a change in cross section. The channel bed profile has gradually reduced 


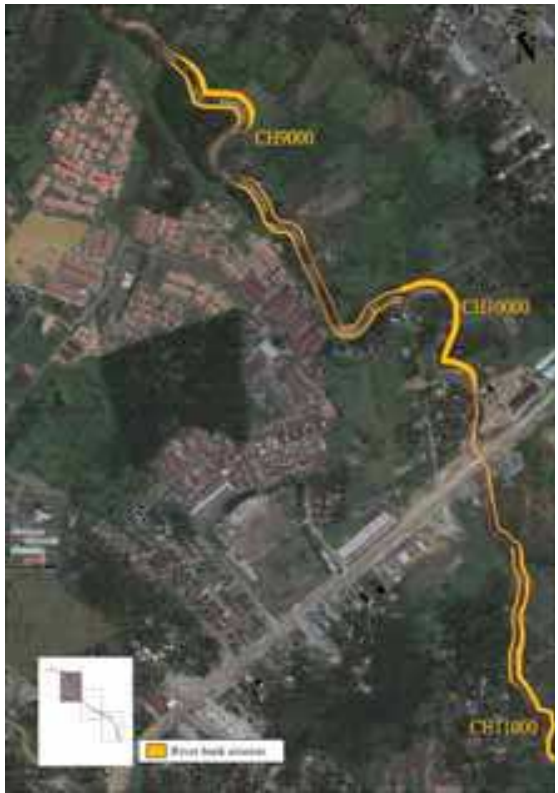

(a) $\mathrm{CH} 9000-\mathrm{CH} 11000$

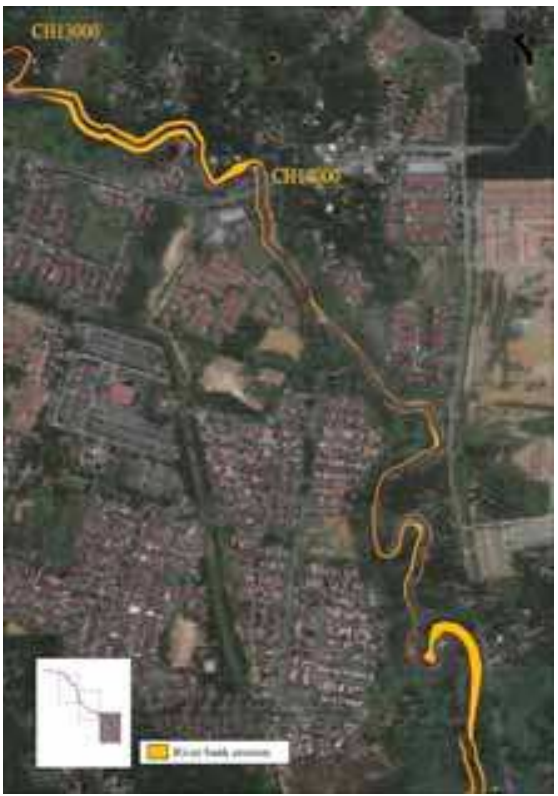

(b) $\mathrm{CH} 13000-\mathrm{CH} 14000$

Fig. 4. Channel Planform of Kulim River (Sirdari, 2009)

within 13 years period, which proves that channel degradation occurred at most cross sections at Kulim River after the flood event (Chang et al., 2005). Thalweg at the $\mathrm{CH} 14390$ has changed from $24.58 \mathrm{~m}$ to $23.50 \pm 0.5 \mathrm{~m}$ and thalweg at the $\mathrm{CH} 3014$ has changed from $8.38 \mathrm{~m}$ to $6.45 \pm$ $0.5 \mathrm{~m}$ (Figure 5). From these results of cross section changes, it's shown that steep slope in Kulim River has induced higher discharge, and it was associated with the spatial variation in sediment transport and sediment size. The changes in river bed profile may be attributed to the erosion or deposition along the banks or the channel width. As a result, the study of changes in channel-bed profile, width variation and changes in bed topography, bank erosion, changes in channel degradation and aggradation, changes in channel curvature and river meandering were also carried out using sediment transport model.

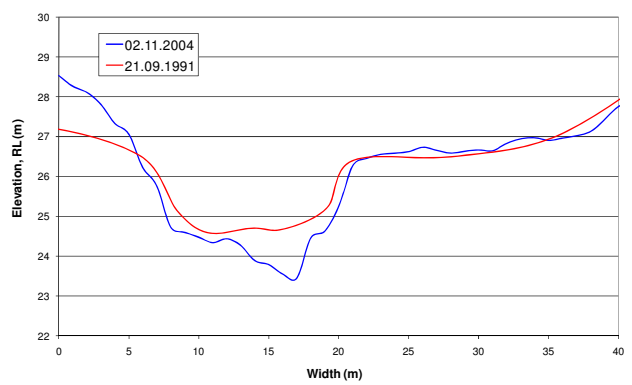

(a) $\mathrm{CH} 14390$

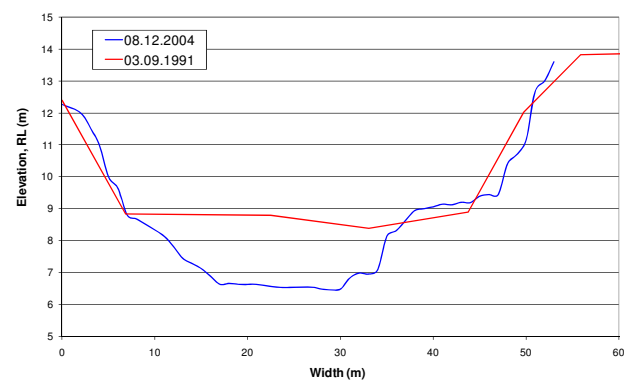

(b) $\mathrm{CH} 3014$

Fig. 5. Cross Section Changes 


\subsection{Sediment transport equation assessment}

The analysis for a total of 22 sets of data based on averaged size of sediment $\left(d_{50}\right)$ have been obtained for nine sediment transport equations including five bed load equations namely Einstein bed load function (Einstein, 1942, 1950), Einstein-Brown's equation (Brown, 1950), Meyer-Peter-Muller's equation (1948), Shields' equation (1936), Duboys' equation (1879) and four total load equations namely Yang's equation (1972), Engelund-Hansen's equation (1967), Ackers-White's equation (1973) and Graf's equation (1971). The performances of the equations were measured using the discrepancy ratio (DR), which is the ratio of the predicted load to measured load ( $\mathrm{DR}=$ predicted/ measured). In this study, a discrepancy ratio of 0.5 to $2.0(\mathrm{DR}=0.5-2.0)$ was used as a criterion in the evaluation of the selected equations. However, the evaluation of these equations shows that all the existing equations, in most cases, over-predicted the measured values, as shown in Table 4 . The result shows that Engelund \& Hansen equations gives better prediction of measured data and yielded the highest percentage of data sets within discrepancy ratio of 0.5 to 2.0 at $\mathrm{CH} 14390(50 \%)$ and $\mathrm{CH} 3014(41.67 \%)$. The analysis also shows that all of the bed load equations gave unsatisfactory performance to predict the sediment load compared to total load equations.

\begin{tabular}{|c|c|c|c|c|}
\hline \multirow[b]{2}{*}{ Sediment Transport Equations } & \multicolumn{2}{|c|}{ CH 14390} & \multicolumn{2}{|c|}{ CH 3014} \\
\hline & $\begin{array}{c}\text { Total of } \\
\text { Data }\end{array}$ & $\begin{array}{c}\text { Total of Data } \\
\text { Falls within } \\
0.5-2.0\end{array}$ & $\begin{array}{l}\text { Total } \\
\text { of Data }\end{array}$ & $\begin{array}{c}\text { Total of Data } \\
\text { Falls within } \\
0.5-2.0\end{array}$ \\
\hline $\begin{array}{l}\text { Einstein Bed Load Function (1942, } \\
\text { 1950) }\end{array}$ & \multirow{9}{*}{12} & 0 & \multirow{9}{*}{10} & 0 \\
\hline Einstein-Brown Equation (1950) & & 0 & & 0 \\
\hline $\begin{array}{l}\text { Meyer-Peter-Müller Equation } \\
\text { (1948) }\end{array}$ & & 0 & & 0 \\
\hline Shields Equation (1936) & & 0 & & 0 \\
\hline Duboys' equation (1879) & & 0 & & 0 \\
\hline Yang's equation (1972) & & 3 & & 5 \\
\hline Engelund-Hansen equation (1967) & & 6 & & 5 \\
\hline Ackers-White's equation (1973) & & 0 & & 1 \\
\hline Graf equation (1971) & & 4 & & 2 \\
\hline
\end{tabular}

Table 4. Summary of Sediment Transport Assessment (Chang, 2006b; Ab. Ghani et al., 2007)

\section{Sediment transport modeling}

\subsection{Software used}

Studies of sediment transport, scour and fill, aggradation and deposition analyses can be performed by computer model simulation. The rapid pace of computer technology has been a milestone for mathematical models in sediment transport. As a result, the high demand on the models resulted in development of many models and the selection of the right model under certain constraints requires a comprehensive knowledge of the capabilities and features of available models. Recently, wide acceptance of a community sediment transport model would make the model a more effective tool for research, planning and design of river engineering, therefore numerous sediment models are available in the study of hydraulic and sediment transport modeling. 
The review of capabilities and performance of sediment transport models has been discussed by the National Research Council (1983), Fan (1988), American Society of Civil Engineers Task Committee on Hydraulics, Bank Mechanics, and Modeling of River Width Adjustment (ASCE, 1998), Federal Interagency Stream Restoration Working Group (FISRWG, 2001) and Department of Water Resources, Resource Agency State of California (DWR, 2004). In addition, applications of the several commonly used sediment transport models have been described by Ab. Ghani et al. (2003) and Chang (2006b). These applications illustrate various capabilities of different models and each sediment transport model has its own limitations. The selection of the right model under certain constraints requires a comprehensive knowledge of the capabilities and features of available models.

The sediment transport model, FLUVIAL-12 (Chang 1982, 1984, 1988), which was first developed in 1972, has been selected for the Kulim River study. FLUVIAL-12 is developed for water and sediment routing in natural and man-made channels. The combined effects of flow hydraulics, sediment transport and river geomorphic changes are simulated for a given flow period. FLUVIAL-12 model is an erodible-boundary model that includes the width adjustment component, which simulates inter-related changes in channel-bed profile, width variation and changes in bed topography induced by the channel curvature effect. Besides that, bank erosion, changes in channel curvature and river meandering can also be modeled (Chang, 2006a).

The applicability of the FLUVIAL-12 model for the river channel responses under its existing conditions and proposed conditions in response to human intervention and the environmental impacts has confirmed by Chang et al. (2002), where FLUVIAL-12 simulations were made based on a 100-year flood as well as a long-term flood series. Besides that, several case studies of FLUVIAL-12 model applications as discussed by Chang (2006b) and Chang et al. (2008) also showed that FLUVIAL-12 was capable to predict river changes caused by nature and human activities, including general scour at bridge crossings, sediment delivery, channel responses to sand and gravel mining and channelization. Sediment delivery is defined as the cumulative amount of sediment that has been delivered passing a certain channel section for a specified period of time (Chang, 2006a).

\subsection{Model input and output}

The study reach covers approximately $14.5 \mathrm{~km}$ of Kulim River, from the upstream $(\mathrm{CH}$ 14390) to the Ara Kuda streamflow station (CH 0). The inputs to the FLUVIAL-12 model are described in detail in FLUVIAL-12 Users Manual (Chang, 2006a).

The geometry data consists of existing survey cross-sections in September 1991 between CH 1900 to $\mathrm{CH} 14390$ at the upstream of Kulim River. How ever, the survey of CH 0 cross section in December 1995 was provided by DID Hydrology Division for the FLUVIAL-12 modeling requirement. In this study, a total of 120 existing survey cross sections were selected along the study reach to define the channel geometry as the input for FLUVIAL-12 model. FLUVIAL-12 has been used to simulate the channel geometry, lateral and vertical elevation changes for the flood events from 1991 to 2006.

The input hydrograph at Ara Kuda for year 1991 (Figure 6) was used for model sensitivity analysis whilst model calibration and validation was using the hydrograph from year 1991 to June 2006 (Figure 7). The rating curve which is used to define discharge variation of stage (water surface elevation) for the downstream boundary condition is shown in Figure 8; the 


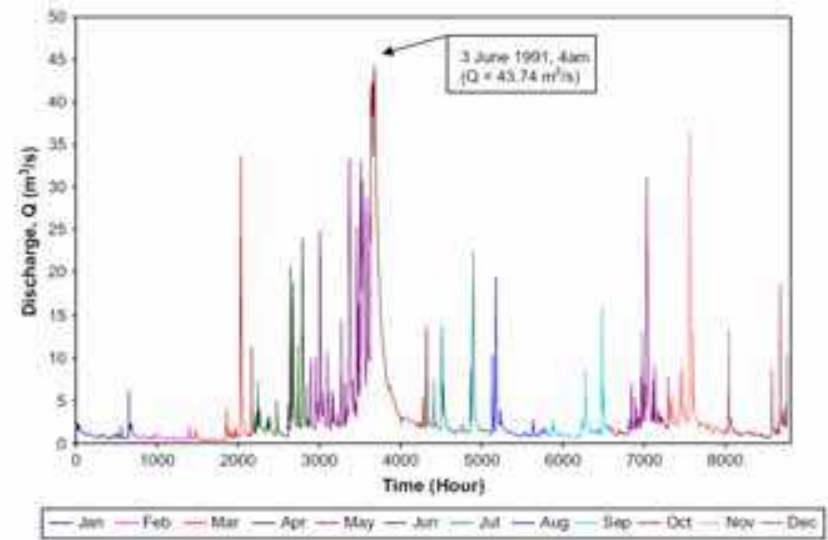

Fig. 6. Input Hydrograph for Year 1991

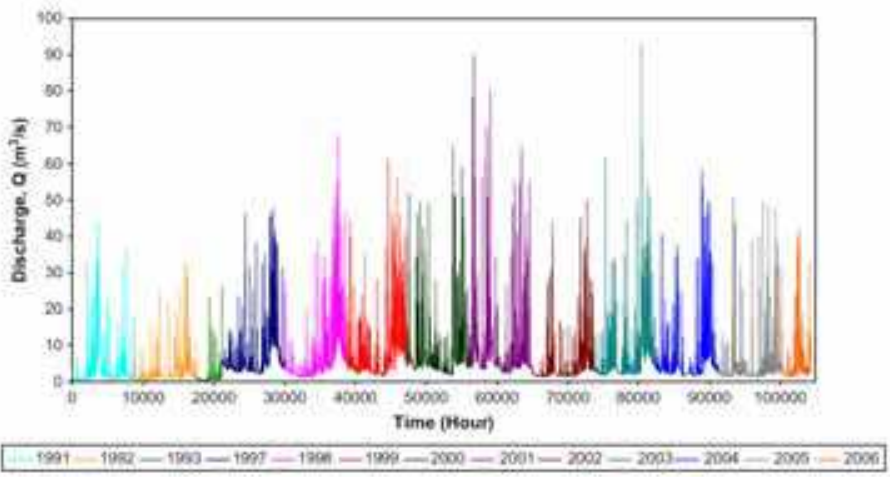

Fig. 7. Input Hydrograph for Year 1991 to June 1993, 1997 to June 2006

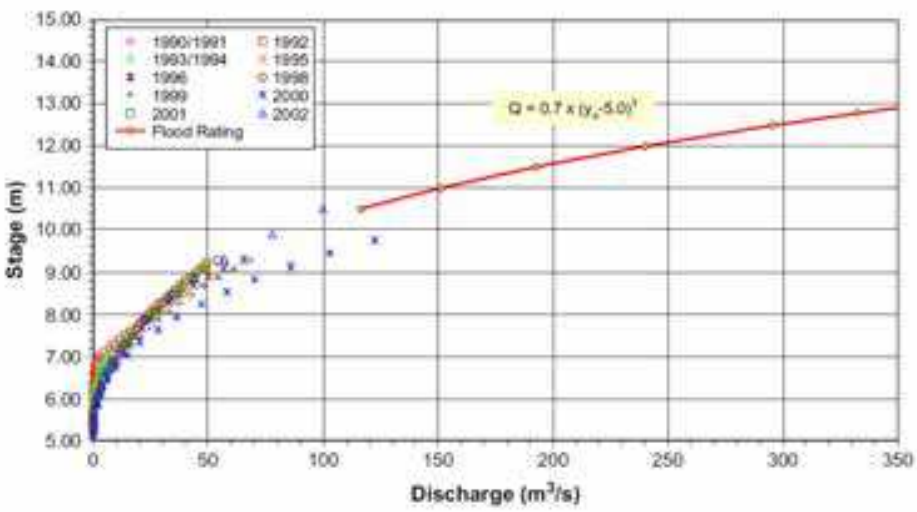

Fig. 8. Flood Rating Curve at Ara Kuda ( $\mathrm{CH} 0)$ 
shifts in stagedischarge relationships reflect the variability at Ara Kuda streamflow station derived from the past 12-year rating curve for Kulim River. The geometric mean of the bed material size fractions is adequately described from the sediment size distribution. Two sediment size distributions of such samples based on sieve analysis are required at the upstream $\left(\mathrm{d}_{50}=1.50 \mathrm{~mm}\right)$ and downstream $\left(\mathrm{d}_{50}=0.75 \mathrm{~mm}\right)$ cross sections to specify initial bed material compositions in the river bed (Figure 9). These input data, can be grouped into the categories of geometry, sediment and hydrology. A summary of the input and output parameter for each category is shown in Table 5.

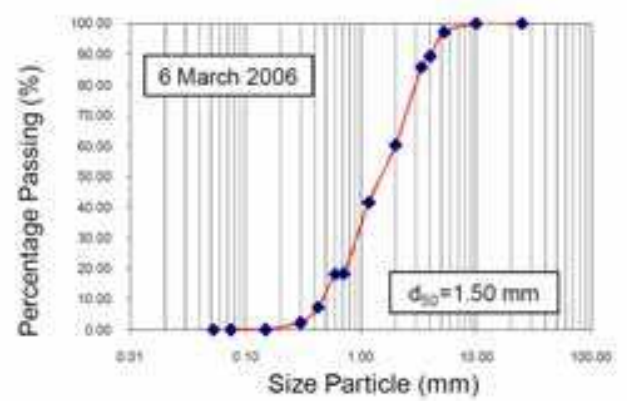

(a) Upstream (CH 14390)

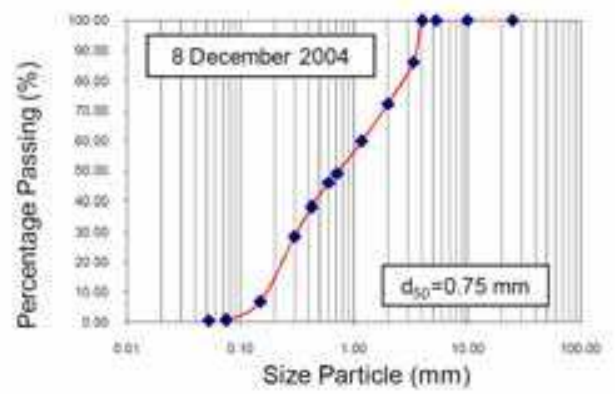

(b) Downstream (CH 3014)

Fig. 9. Initial Bed Material Size Distributions

\begin{tabular}{|c|c|c|c|c|}
\hline Category & Category & Parameter & Value & Source \\
\hline \multirow[t]{7}{*}{$\begin{array}{l}\text { Input } \\
\text { Parameter }\end{array}$} & \multirow[t]{4}{*}{ Geometry } & Cross section & $\begin{array}{l}\text { per section } \\
\text { (Total of cross sections = } \\
120 \text { ) }\end{array}$ & $\begin{array}{l}\text { CH } 1900 \text { - CH } 14390 \text { (DD } 1991 \\
\text { Survey) } \\
\text { CH } 0 \text { (DD } 1995 \text { Survey) }\end{array}$ \\
\hline & & Reach lengths & $\begin{array}{l}\text { per section } \\
(\text { Total length }=14.4 \mathrm{~km})\end{array}$ & 1991 (DD 1991 Survey) \\
\hline & & $\begin{array}{l}\text { Roughness } \\
\text { coefficient }\end{array}$ & $\begin{array}{l}\text { Same by cross section } \\
\text { ( } n=0.020,0.025,0.030 \\
0.035,0.040 \text { were } \\
\text { evaluated during the } \\
\text { sensitivity analysis) }\end{array}$ & Values static at all levels of flow. \\
\hline & & $\begin{array}{l}\text { Radius of } \\
\text { curvature }\end{array}$ & per section & 1991 (DD 1991 Survey) \\
\hline & \multirow[t]{3}{*}{ Sediment } & $\begin{array}{l}\text { Sediment } \\
\text { samples }\end{array}$ & $\begin{array}{l}2 \text { sediment size } \\
\text { distributions of such } \\
\text { samples are required } \\
\text { (upstream and } \\
\text { downstream section) }\end{array}$ & $\begin{array}{l}\text { Data sampling at CH } 14390 \text { (Year } \\
\text { 2006) and CH } 0 \text { (Year 2004) }\end{array}$ \\
\hline & & $\begin{array}{l}\text { Regular non- } \\
\text { erodible bank }\end{array}$ & $\begin{array}{l}\text { Generally fix at left and } \\
\text { right bank, varies by cross } \\
\text { section }\end{array}$ & DID 1991 Survey \\
\hline & & $\begin{array}{l}\text { Sediment } \\
\text { transport } \\
\text { formula }\end{array}$ & $\begin{array}{l}\text { Seven sediment transport } \\
\text { formulas were evaluated } \\
\text { during the sensitivity } \\
\text { analysis }\end{array}$ & $\begin{array}{l}\text { Graf's sediment formula (1971) } \\
\text { Yang's unit stream power } \\
\text { formula (1972) } \\
\text { Engelund-Hansen sediment }\end{array}$ \\
\hline
\end{tabular}




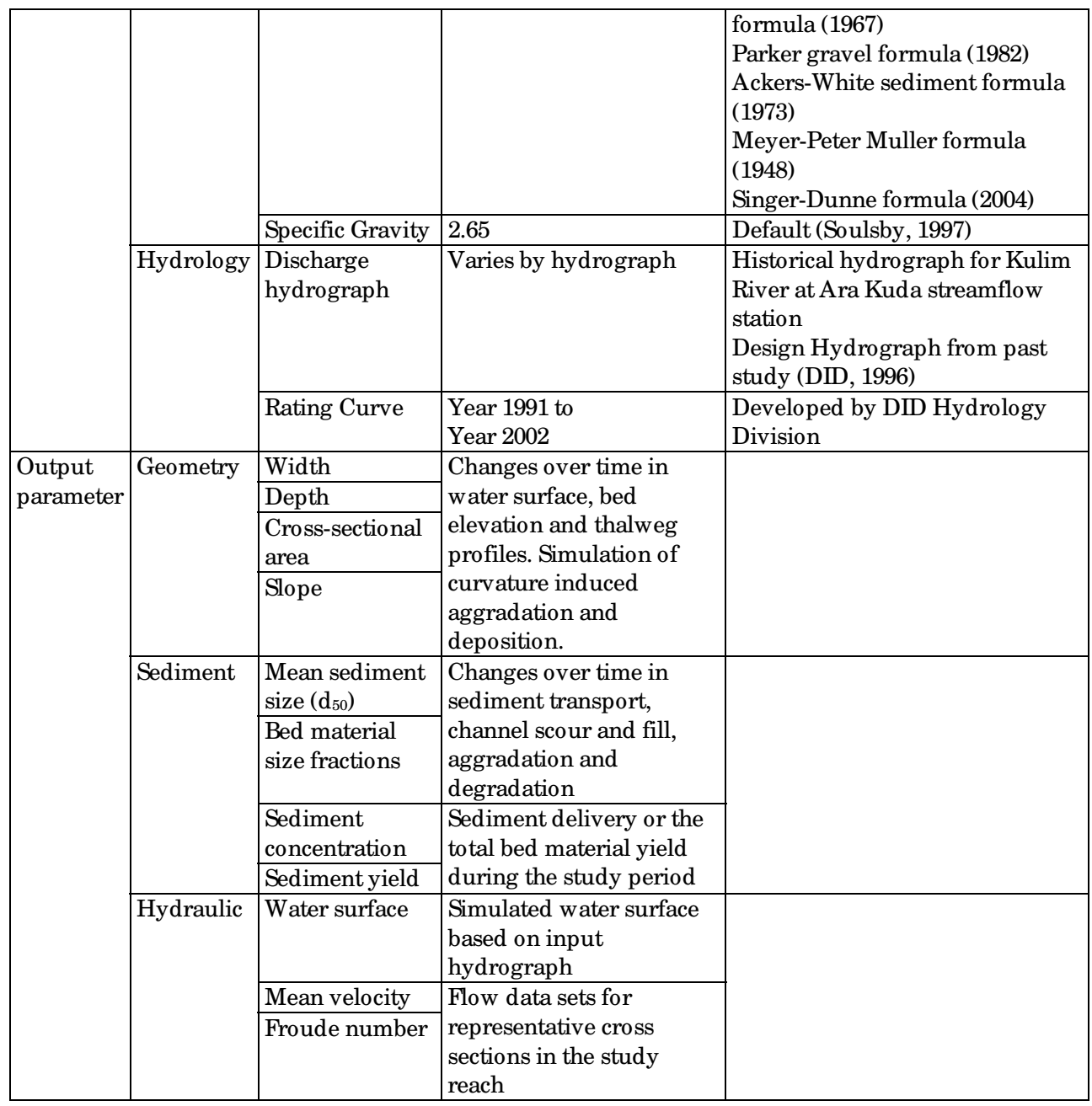

Table 5. Summary of Input and Output Parameter for FLUVIAL-12 in Present Study (Chang et al., 2008)

\subsection{Sensitivity analysis}

An analysis was conducted to evaluate the sensitivity of the modelling results to changes in input parameters. To determine the sensitivity of FLUVIAL-12, which including flow, sediment transport and the channel geomorphic changes caused by the variation of each parameter, different values of the parameter were used in simulation runs and the results obtained are compared. Sensitivity analysis is an important step to be taken for more effective use of a model. Major items that required sensitivity test include roughness coefficient, sediment transport equations, channel curvature and number of cross section (reach length between two sections). This sensitivity analysis was carried out using the 
existing survey cross section and hydrograph for the year of 1991. However, the accuracy of the model is limited to the quality and quantity of the input data. Therefore, using available hydraulic and hydrology data including cross section spacing will affect the quality of the output data. Besides that, selection of the sediment transport formula and model calibration for roughness coefficient are also essential. Table 6 shows the summary of the sensitivity analysis for Sungai Kulim using FLUVIAL-12.

\begin{tabular}{|l|l|l|}
\hline \multicolumn{1}{|c|}{ Parameter } & \multicolumn{1}{|c|}{ Values Tested } & \multicolumn{1}{c|}{ Comments } \\
\hline Roughness Coefficient & Range: 0.020-0.050 & $\begin{array}{l}\text { Started out with values recommended in the } \\
\text { 0.020. Some values were then changed. } \\
\text { Water Surface is increasing when roughness } \\
\text { coefficient increasing. }\end{array}$ \\
\hline $\begin{array}{l}\text { Sediment Transport } \\
\text { Equation }\end{array}$ & $\begin{array}{l}7 \text { sediment } \\
\text { transport equations }\end{array}$ & $\begin{array}{l}\text { All equations were tested due to field } \\
\text { observation. Selection of the proper and } \\
\text { applicable sediment transport formula is } \\
\text { essential. }\end{array}$ \\
\hline Channel Curvature & $\begin{array}{l}\text { Zero curvature and } \\
\text { curvature }\end{array}$ & $\begin{array}{l}\text { Simulation of curvature induced } \\
\text { aggradation and deposition in the model } \\
\text { based on the flow curvature. }\end{array}$ \\
\hline $\begin{array}{l}\text { Number of Cross } \\
\text { Sections }\end{array}$ & 120,62 and 32 & $\begin{array}{l}\text { Shortened distance between cross section or } \\
\text { closely spaced along a reach produce more } \\
\text { accuracy result in channel geometry } \\
\text { changes. }\end{array}$ \\
\hline
\end{tabular}

Table 6. Summary of Sensitivity Analysis

\subsection{Model calibration and validation}

The simulation of the FLUVIAL-12 was obtained using 1991 cross section survey and hydrograph. Based on measured water levels, predictions using both roughness coefficients are close to the observed data during low flow. However, as the field data was not available from year 1991 to 2003, a long-term simulation has been carried out to calibrate and validate the model based on the recent measured water level and bed level data that were obtained from 2004 to 2006. Therefore, the calibration of the roughness coefficient using measured water level and bed level in November 2004 is done. As a part of the calibration procedure, the model was run for 12-year period between 1991 to 1992 and 1997 to 2006.

The results of the model simulation during the calibration period agree very well (Table 7 and Figure 10), and it can be concluded that prediction using roughness coefficient $n=0.030$ and Engelund-Hansen formula were in good agreement with measured water levels and bed profiles and used for model validation. As a part of validation, measured water levels and bed profiles, during September 1991, January 2005 and March 2006 was compared to the predicted water levels and bed profiles by FLUVIAL-12 (Table 8). Longterm simulations including of the historical flood events showed very good results for both calibration and validation. Good agreements were obtained for both water level and bed levels between the measured and predicted by FLUVIAL-12 model. 


\begin{tabular}{|c|c|c|c|c|c|c|c|c|c|c|c|}
\hline \multirow{3}{*}{$\begin{array}{c}\text { Roughness } \\
\text { coefficient } \\
n\end{array}$} & \multirow{3}{*}{ Location } & \multicolumn{5}{|c|}{ Water Level (m) } & \multicolumn{5}{|c|}{ Thalweg Level (m) } \\
\hline & & \multirow[t]{2}{*}{ Measured } & \multicolumn{2}{|c|}{ Yang fomula } & \multicolumn{2}{|c|}{$\begin{array}{c}\text { Engelund-Hansen } \\
\text { fomula }\end{array}$} & \multirow{2}{*}{ Measured } & \multicolumn{2}{|c|}{ Yang fomula } & \multicolumn{2}{|c|}{$\begin{array}{c}\text { Engelund-Hansen } \\
\text { fomula }\end{array}$} \\
\hline & & & Predicted & Difference & Predicted & Difference & & Predicted & Difference & Predicted & Difference \\
\hline \multirow{4}{*}{0.025} & $\mathrm{CH} 0$ & 7.45 & 7.80 & +0.35 & 7.80 & +0.35 & 5.05 & 5.34 & +0.29 & 5.29 & +0.24 \\
\hline & CH 3014 & 8.61 & 8.14 & -0.47 & 8.13 & -0.48 & 6.66 & 6.79 & +0.13 & 6.96 & +0.30 \\
\hline & CH 8185 & 13.55 & 12.47 & -1.08 & 13.67 & +0.12 & 12.27 & 11.68 & -0.59 & 12.85 & +0.58 \\
\hline & $\begin{array}{c}\mathrm{CH} \\
14390\end{array}$ & 25.61 & 26.00 & +0.39 & 25.99 & +0.38 & 23.45 & 24.58 & +1.13 & 24.58 & +1.13 \\
\hline \multirow{4}{*}{0.030} & $\mathrm{CH} 0$ & 7.45 & 7.80 & +0.35 & 7.82 & +0.37 & 5.05 & 5.40 & +0.35 & 5.27 & +0.22 \\
\hline & CH 3014 & 8.61 & 8.36 & -0.25 & 8.29 & -0.32 & 6.66 & 6.57 & -0.09 & 6.69 & +0.03 \\
\hline & CH 8185 & 13.55 & 13.00 & -0.55 & 13.36 & -0.19 & 12.27 & 11.87 & -0.40 & 12.16 & -0.11 \\
\hline & $\begin{array}{c}\mathrm{CH} \\
14390\end{array}$ & 25.61 & 26.17 & +0.56 & 26.14 & -0.53 & 23.45 & 24.58 & +1.13 & 24.58 & 0.00 \\
\hline \multirow{4}{*}{0.035} & $\mathrm{CH} 0$ & 7.45 & 7.80 & +0.35 & 7.93 & +0.48 & 5.05 & 5.33 & +0.28 & 5.26 & +0.21 \\
\hline & CH 3014 & 8.61 & 8.59 & +0.02 & 8.52 & -0.09 & 6.66 & 7.30 & +0.64 & 7.53 & +0.87 \\
\hline & CH 8185 & 13.55 & 13.55 & 0.00 & 13.45 & -0.10 & 12.27 & 12.26 & -0.01 & 12.31 & +0.04 \\
\hline & $\begin{array}{c}\mathrm{CH} \\
14390\end{array}$ & 25.61 & 26.20 & +0.59 & 26.29 & +0.68 & 22.85 & 24.58 & +1.73 & 24.58 & +1.73 \\
\hline
\end{tabular}

Table 7. Comparison of Simulated Water Level and Bed Profile with Measured Data during 2 Nov 2004 for Roughness Coefficient $n=0.025,0.030$ and 0.035 (Chang et al., 2008)
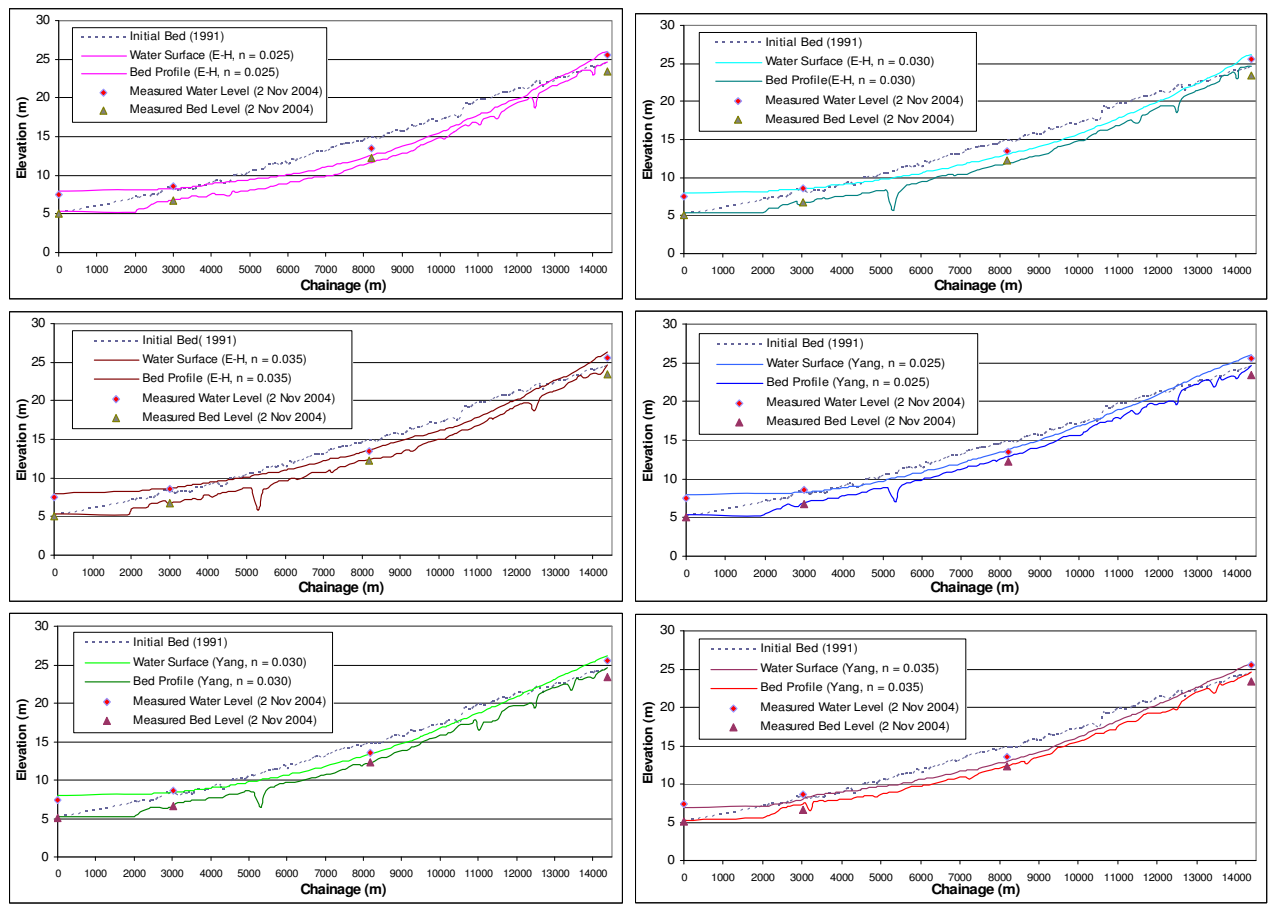

Fig. 10. Comparison of Water Level and Bed Profile for Roughness Coefficient $\mathrm{n}=0.025$, 0.030 and 0.035 (2 Nov 2004) 


\begin{tabular}{|c|l|c|c|c|c|c|c|}
\hline \multirow{2}{*}{ Date } & \multirow{2}{*}{ Location } & \multicolumn{3}{|c|}{ Water Level (m) } & \multicolumn{3}{c|}{ Thalweg Level (m) } \\
\cline { 2 - 8 } & & Measured & Predicted & Difference & Measured & Predicted & Difference \\
\hline \multirow{5}{*}{ 20 September 1991 } & CH 0 & 6.40 & 6.00 & -0.40 & 5.05 & 5.34 & +0.29 \\
\cline { 2 - 9 } & CH 10195 & 18.25 & 18.07 & -0.18 & 6.66 & 6.79 & +0.13 \\
\cline { 2 - 9 } & CH 10438 & 18.53 & 18.39 & -0.14 & 12.27 & 11.68 & -0.59 \\
\cline { 2 - 9 } & CH 14091 & 24.84 & 24.67 & -0.17 & 23.45 & 24.58 & +1.13 \\
\cline { 2 - 9 } & CH 14206 & 24.86 & 24.80 & -0.06 & N/ A & N/ A & N/ A \\
\hline \multirow{5}{*}{ 11 January 2005 } & CH 0 & 6.10 & 6.09 & -0.01 & 5.20 & 5.26 & +0.06 \\
\cline { 2 - 9 } & CH 10195 & 7.03 & 7.19 & +0.16 & 6.50 & 6.59 & +0.09 \\
\cline { 2 - 9 } & CH 10438 & 17.32 & 17.14 & -0.18 & 16.81 & 16.91 & +0.10 \\
\cline { 2 - 9 } & CH 14091 & 24.52 & 25.09 & +0.57 & 23.42 & 24.58 & +1.16 \\
\hline & CH 0 & 5.90 & 5.96 & +0.06 & 5.20 & 5.27 & +0.07 \\
\hline & CH 10195 & 7.38 & 7.05 & -0.33 & 6.48 & 6.46 & -0.02 \\
\hline & CH 10438 & 24.36 & 24.99 & +0.63 & 24.04 & 24.58 & +0.54 \\
\hline & CH 14390 & 25.61 & 26.20 & +0.59 & 22.85 & 24.58 & +1.73 \\
\hline
\end{tabular}

Table 8. Comparison of Simulated Water Level and Bed Profile with Measured Data

\subsection{Model simulation}

Engelund-Hansen formula and roughness coefficient $n=0.030$ were found to be the best combination to represent the sediment transport activity in the study reach throughout the model calibration and validation. The sediment transport modeling was conducted based on three scenarios. These include the existing condition modeling using October 2003 flood hydrograph, future condition modeling by using the design flood hydrograph for the Kulim River based on 2010 landuse (DID, 1996) and long-term modeling by relicensing the time frame using hydrograph for year 1991-1992 and 1997-2006 to predict future ongoing changes for the next 10 years.

The peak discharge of $92.90 \mathrm{~m}^{3 /} \mathrm{s}$ measured on 5 October 2003 , which was the highest discharge measured in a 42-year period since 1960 is adopted as the design peak discharge for existing condition. Consequently, sediment transport modeling was carried out for this flood event (3 to 19 October 2003) as shown in Figure 11. Spatial variations of the sediment delivery during the October 2003 flood are shown in Figure 12. Sediment delivery generally decreased towards downstream especially near to the river sand mining site at $\mathrm{CH} 5064$. This pattern indicated that erosion occurred at upstream and more sediment deposited at downstream of Kulim River.

Peak water surface and changes of the channel geometry due to scour and fill were depicted by the simulated changes in channel bed profile as illustrated in Figure 13. From the simulation results, flood level was higher at the downstream compare to the upstream of Kulim River. Whilst, the results also show that scour of the bed occurred at upstream and the cross sections near to the sand mining area ( $\mathrm{CH}$ 5064) were subjected to greater changes than other cross sections. Commonly, channel degradation was predicted at most cross sections at Kulim River after the flood event. 
Figure 14 shows the sediment transport rates at peak discharge during 2003 flood along the river. Figure 15 shows the example of cross section changes for several locations along Kulim River. In general, the river is stable at most locations after October 2003 flood with the exception of $\mathrm{CH} 5306$ and $\mathrm{CH} 12490$ where lateral migration is predicted at these two locations.

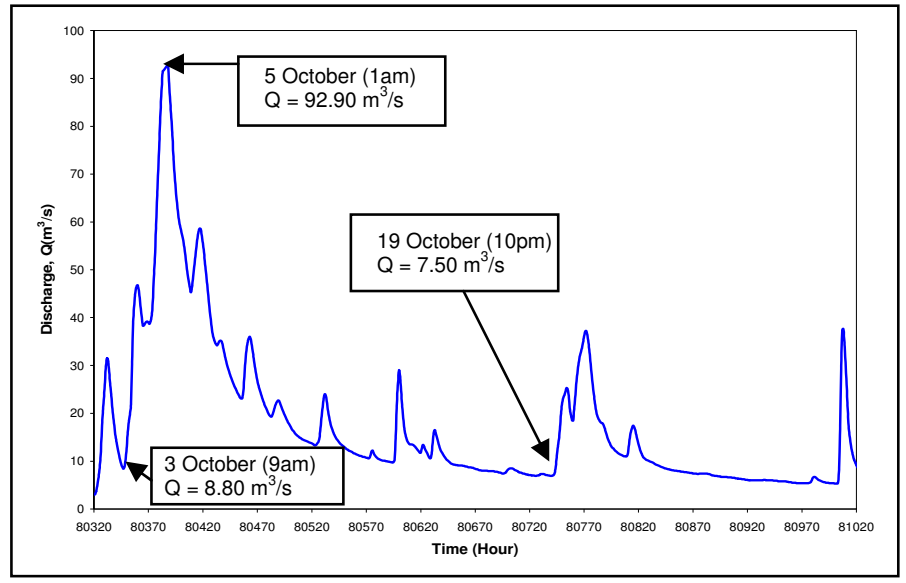

Fig. 11. Hydrograph of the October 2003 Flood at Ara Kuda (CH 0)

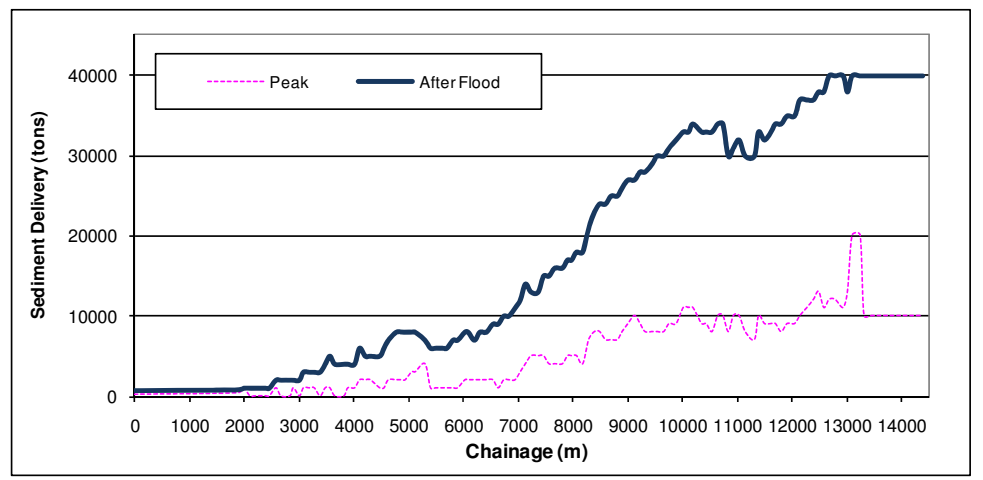

Fig. 12. Spatial Variations of the Sediment Delivery during the October 2003 Flood 


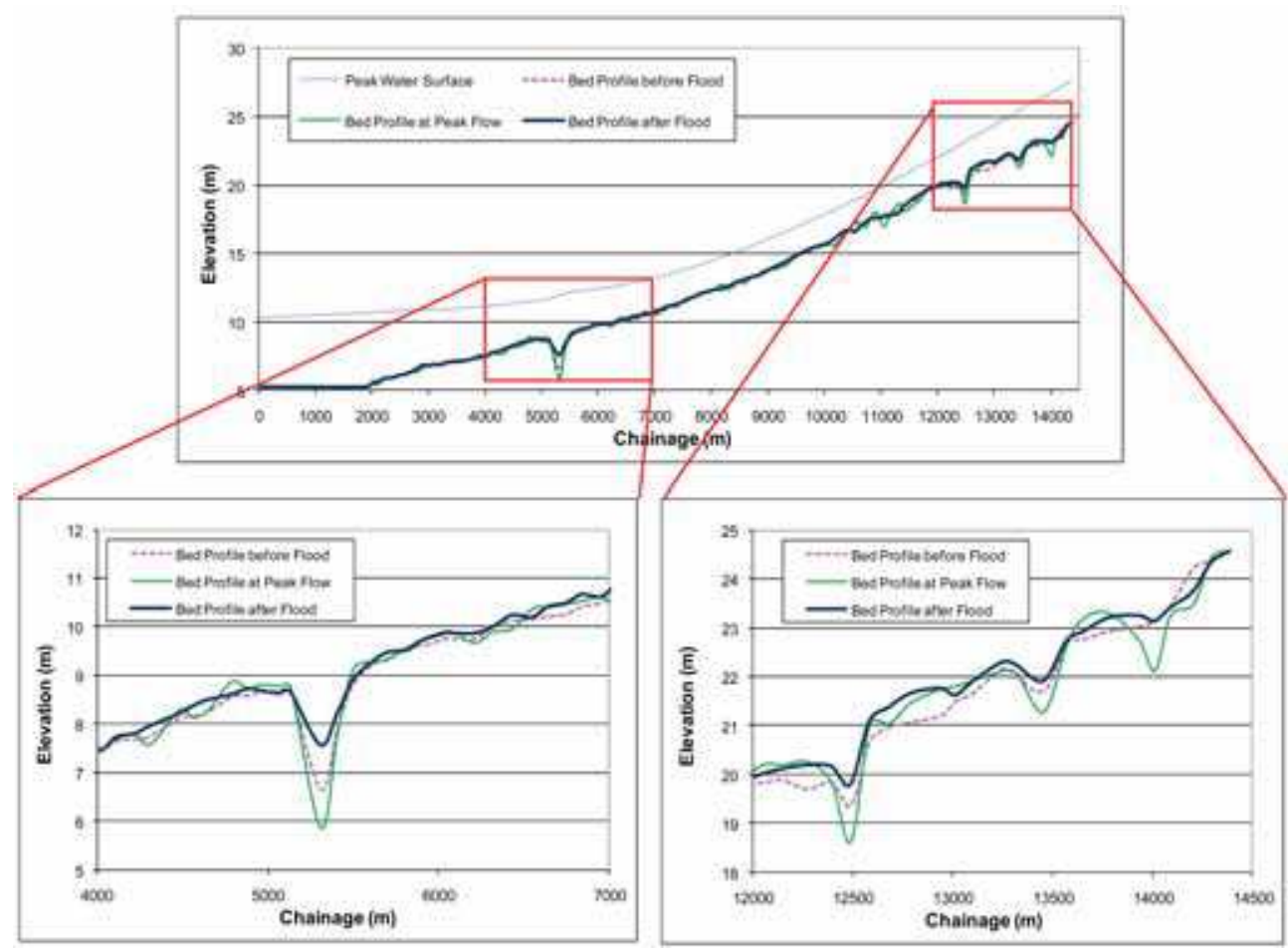

Fig. 13. Prediction of Water surface and Bed Profile Changes during October 2003 Flood

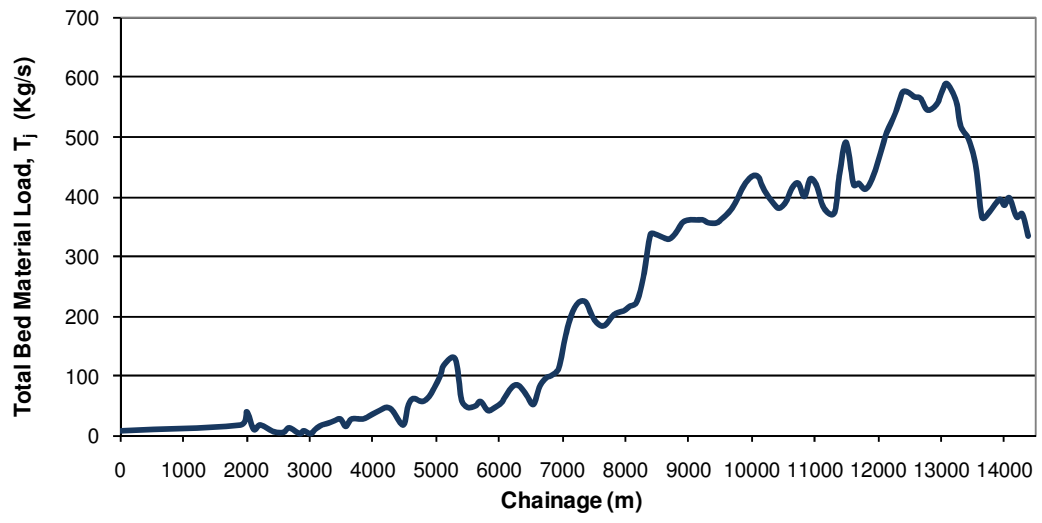

Fig. 14. Sediment Transport Rate at Peak during October 2003 Flood 

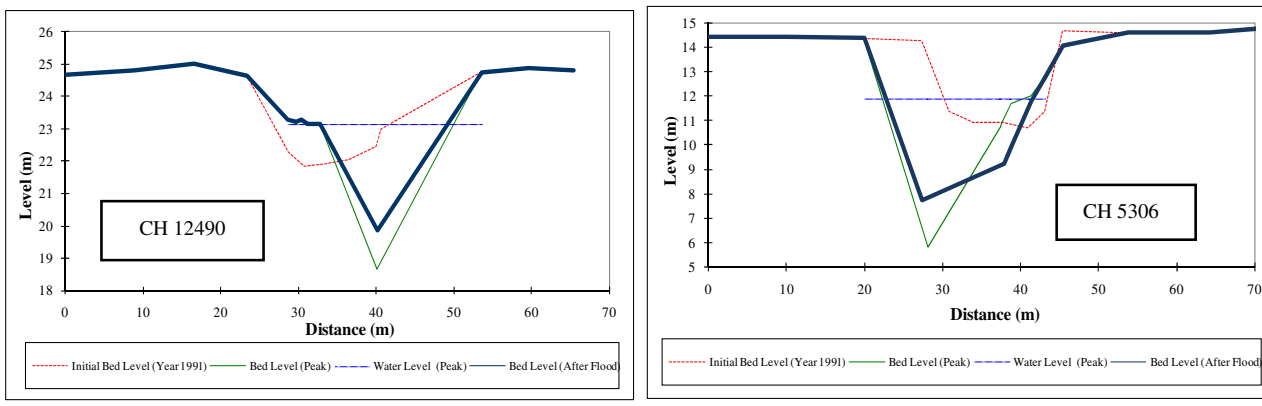

---- Initial Bed Level (Year 1991) —— Bed Level (Peak) —— Water Level (Peak) —— Bed Level (After Flood
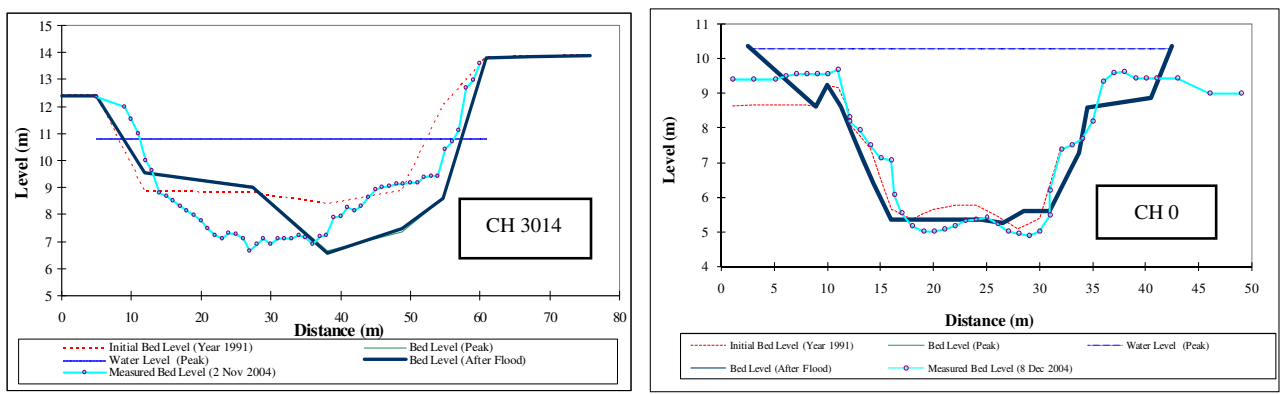

Fig. 15. Modeled Cross Section Changes before and after October 2003 Flood

The design flood hydrograph for the Kulim River based on 2010 landuse (DID, 1996) is shown in Figure 16. The critical peak flow of the event is $306.6 \mathrm{~m}^{3 / \mathrm{s}}$ (18-hour rainfall duration). Simulated peak water surface and channel bed changes for Kulim River based on design hydrograph are shown in Figure 17. The cross sections especially near to the sand mining area and few cross sections especially $\mathrm{CH} 10000$ to $\mathrm{CH} 14390$ were subjected to greater changes than other cross sections. In spite of this, channel degradation was predicted at most cross sections after the peak. Figure 18 shows the cross section changes for two selected locations along Kulim River.

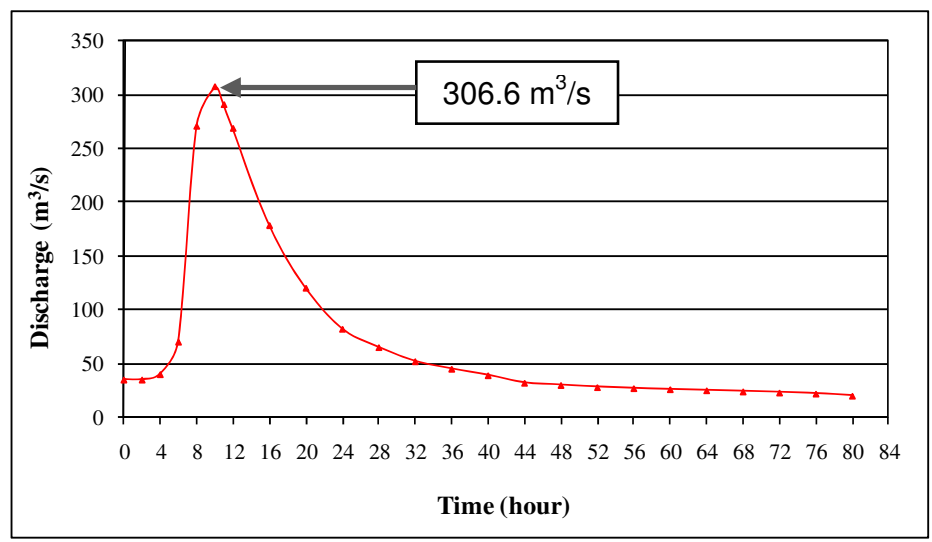

Fig. 16. Design Hydrograph for 2010 Landuse (DID, 1996) 


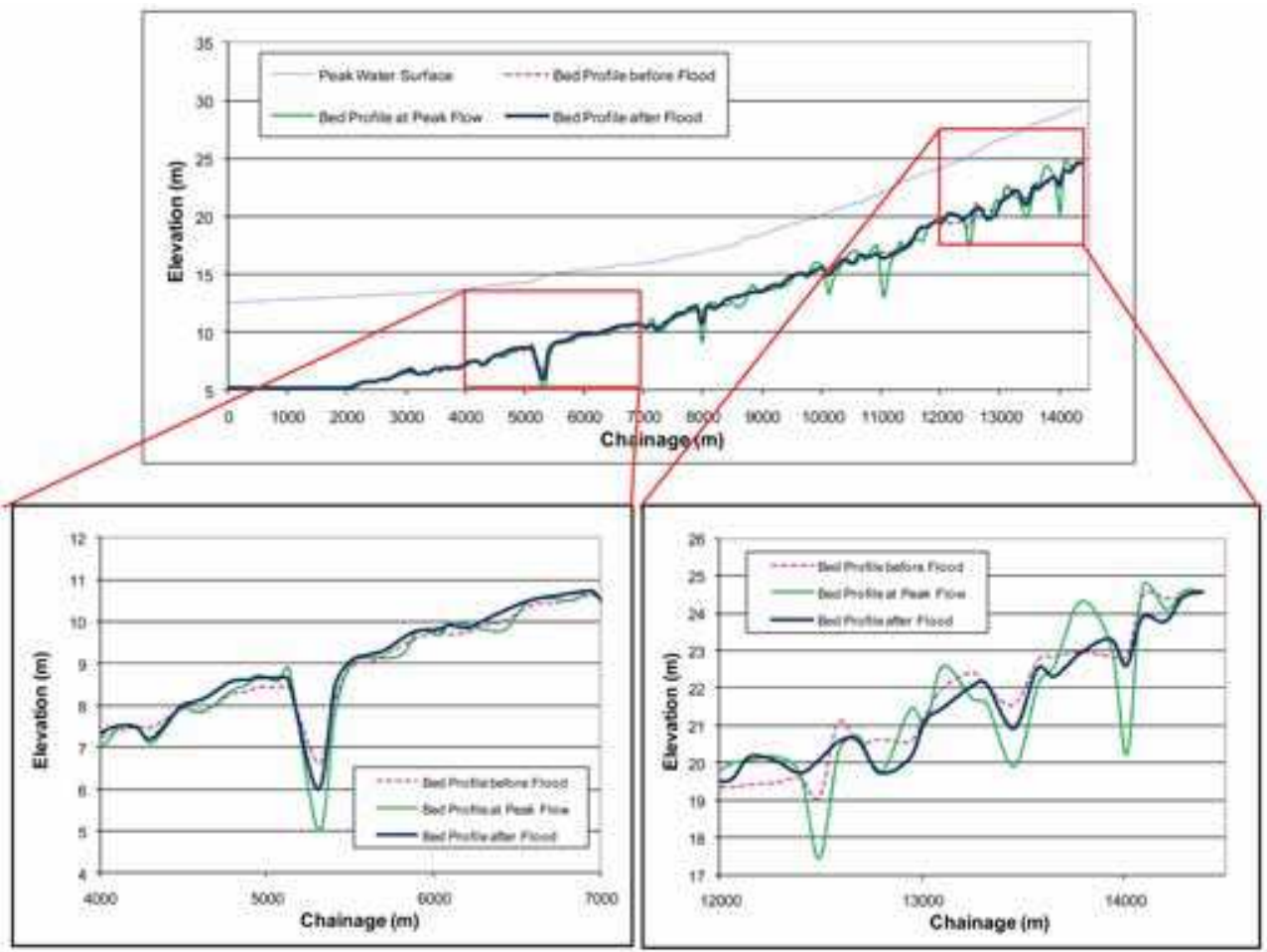

Fig. 17. Water Surface and Bed Profile Changes based on Design Hydrograph
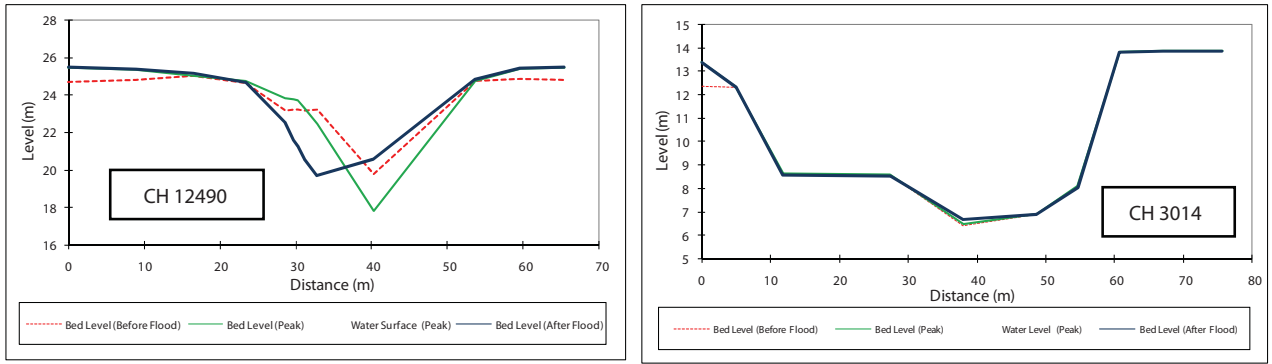

Fig. 18. Modeled Cross Section Changes before and after Design Flood

FLUVIAL-12 model was run to predict the channel geometry changes and sediment delivery for the next 10 years. Future changes for the next 10 years were simulated by using hydrograph as shown in Figure 7, which consists of 50-year ARI and 100-year ARI flood events. Sediment delivery or the amounts of sediment moving past each cross section predicted for the next 10 years (Year 2016) is shown in Figure 19. The simulation results show that the amount of sediment delivery was twice for year 2016 compared to the year 2006, but lesser sediment delivery at the downstream of Kulim River. The decreasing trend of sediment delivery indicates long-term sediment deposition at the downstream of Kulim River. 
Simulation for Kulim River based on the time series illustrated the changes of the channel geometry as shown in Figure 20. The cross sections especially CH 10000 to $\mathrm{CH} 14000$ are subjected to change with sediment aggradation, whilst sediment deposition occur at $\mathrm{CH}$ 6000 to $\mathrm{CH} 10000$. Figure 21 shows the spatial variations of the predicted median grain size in year 2006 and 2016. The model run shows a large decrease in the sediment size at middle reach of Kulim River between years 2006 to 2016; where the reach-mean sediment size

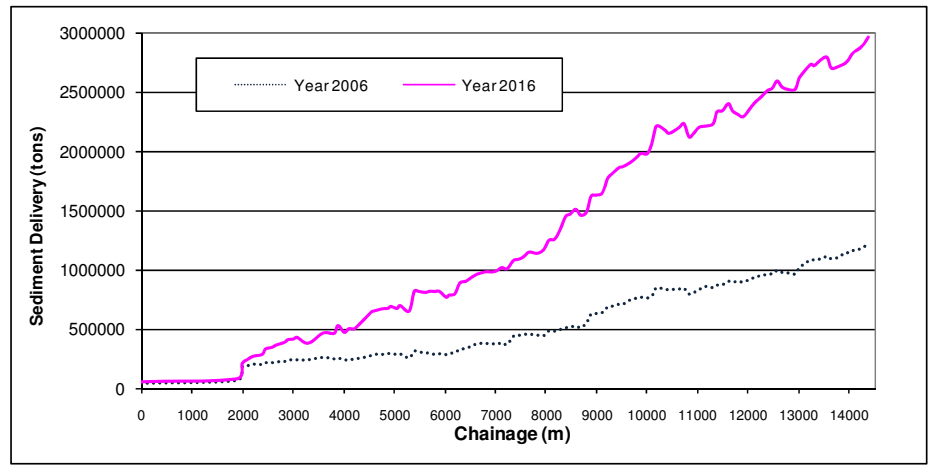

Fig. 19. Spatial Variations of the Predicted Sediment Delivery

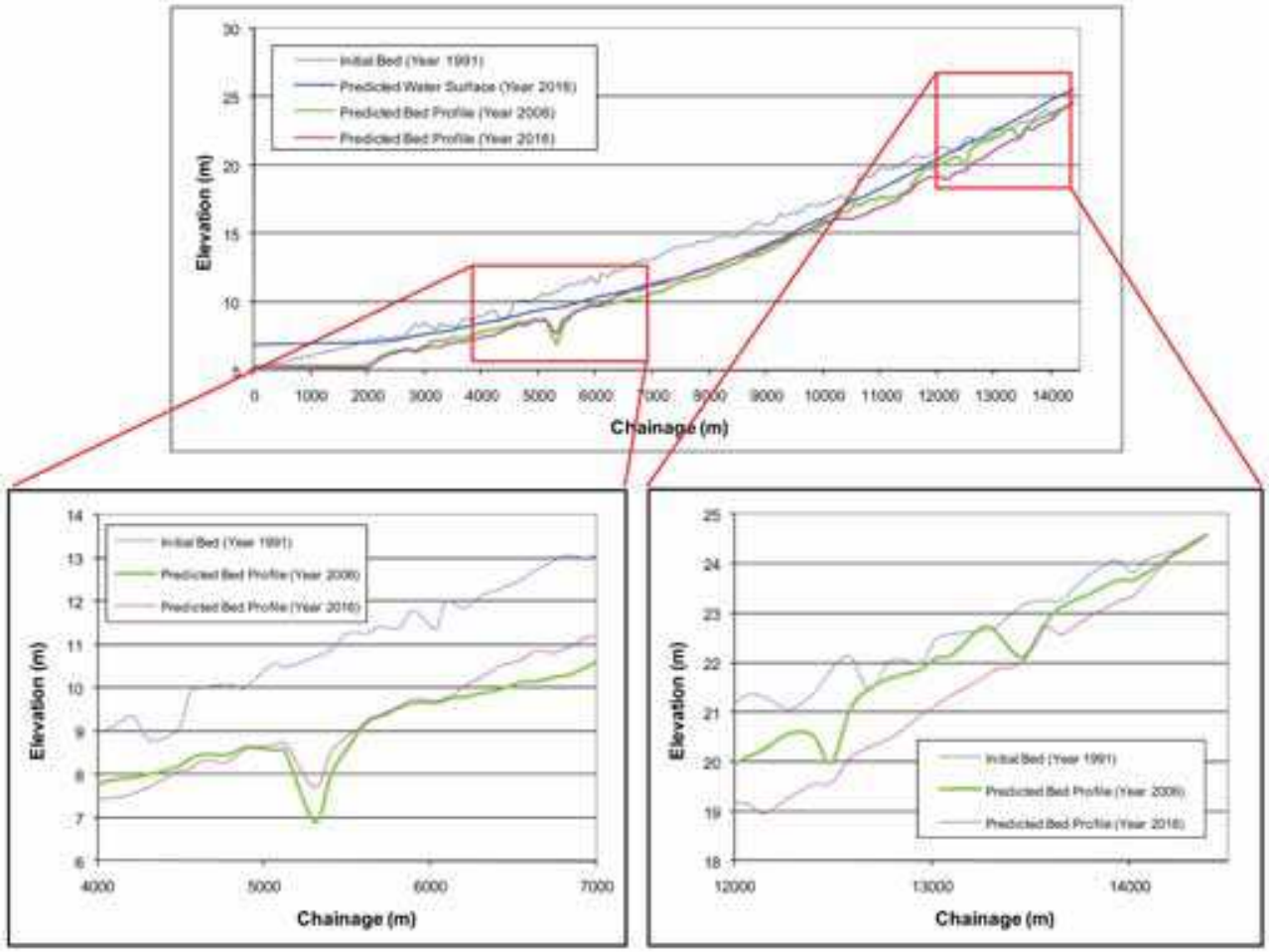

Fig. 20. Water Surface and Bed Profile Changes based on Design Hydrograph 


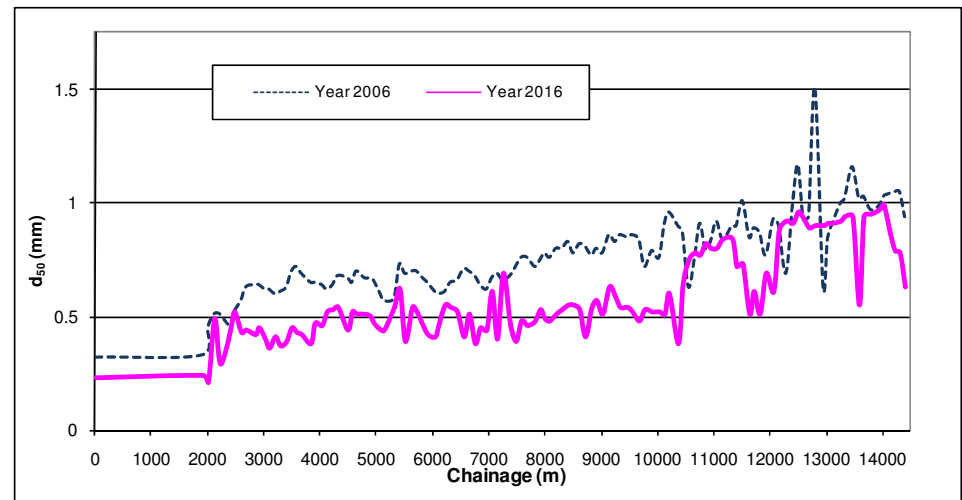

Fig. 21. Spatial Variations of the Predicted Median Grain Size for Year 2006 and 2016
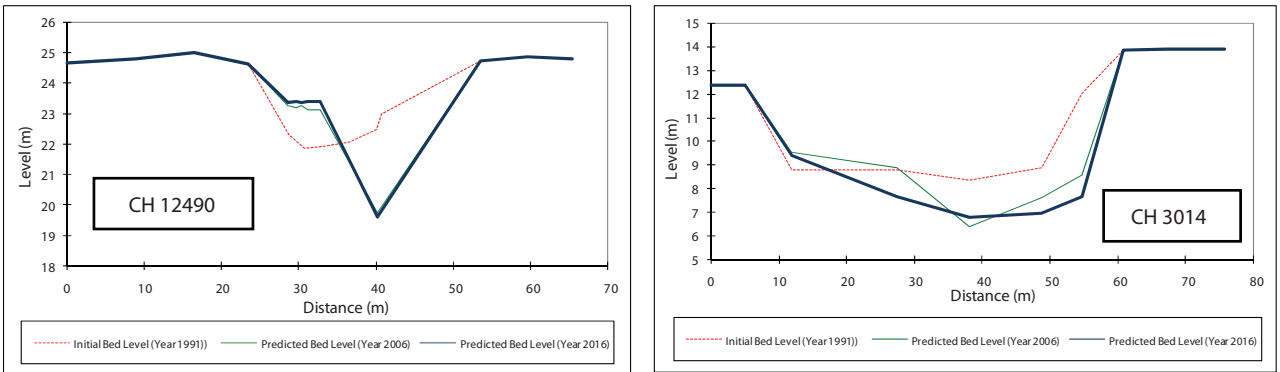

Fig. 22. Predicted Cross Section Changes for Year 2006 and 2016

decrease from $0.77 \mathrm{~mm}$ to $0.58 \mathrm{~mm}$. As the channel bed became finer, more sediment was removed by erosion. Figure 22 shows the example of cross section changes for three locations along Kulim River.

In general, it is found that Kulim River will be in equilibrium conditions with slight degradation or erosion which deepen the river. The modeled results show that future changes in cross sectional geometry will generally be limited and erosion along the reach will be slowed down in the simulation period from 2006 to 2016. Thus, Kulim River was predicted to be stable at most locations.

\section{Conclusion}

Flooding in Kulim River is found to affect channel geometry, cross sectional geometry, sediment size and sediment delivery, which consists of scour and fill. Three scenarios was evaluated for Kulim River; the model simulation results for existing conditions, future conditions and long-term modeling show that the sediment size and channel geometry in Kulim River changed significantly and the amount of sediment delivery trend decrease with time indicates that long term sediment aggradation occurred at upstream and deposition occurred at downstream of Kulim River. However, modeled results show that future changes in cross sectional geometry will be limited and erosion along the reach will slow down from 2006 to 2016 . The results based on the water surface profile simulated from the 
model should also be considered that the proposed bund level and bank protection should stay above the predicted water surface to avoid overtopping and reduce the flooding impact. The present study provides an estimate of sediment transport in moderate sandy stream and serves as a reference for sediment transport modeling of sandy streams in Malaysia and overseas.

\section{References}

Ab. Ghani, A., Ali, R., Zakaria, N.A., Abu Hasan, Z., Chang, C.K. \& Ahamad, M.S.S. (2010). A Temporal Change Study of the Muda River System over 22 Years. International eburnal of River Basin Management, IAHR \& INBO. Vol. 8, No. 1, 25-37. ISSN: 15715124 .

Ab. Ghani, A., Zakaria, N.A., Abdullah, R., Chang, C.K., Sinnakaudan, S.K., Mohd Sidek, L. (2003). Guidelines for Field Data Collection and Analysis of River Sediment. Department of Irrigation and Drainage Malaysia, Kuala Lumpur. 35 pp.

Ab. Ghani, A., Zakaria, N.A., Chang, C.K., Ariffin, J., Abu Hasan, Z., Abdul Ghaffar, A.B. (2007). Revised Equations for Manning's Coefficient for Sandbed Rivers. International eburnal of River Basin Management, Vol. 5, No. 4, 329-346. ISSN: 15715124.

American Society of Civil Engineers or ASCE (1998). River width Adjustment II: Modeling, by the ASCE Task Committee on Hydraulics, Bank Mechanics, and Modeling of River Width Adjustment. eburnal of Hydraulic Engineering, 124 (9), 903-917. ISSN: 0733-9429.

Chang, H.H. (1982). Mathematical Model for Erodible Channels. eburnal of the Hydraulics Division, 108 (HY5), 678-689. ISSN: 0733-9429.

Chang, H.H. (1984). Modeling of River Channel Changes. cburnal of Hydraulic Engineering 110 (2), 265-267. ASCE157-172. Closure in 113(2), 1987. ISSN: 0733-9429.

Chang, H.H. (1988). Fluvial Processes in River Engineering. John Wiley and Sons, ISBN: 0-47163139-6, New York. 432pp.

Chang H. H., Pearson, D. \& Tanious, S. (2002). Lagoon Restoration near Ephemeral River Mouth. eburnal of Waterway, Port, Coastal, and Ocean Engineering, Vol. 128, No.2, 7987. ISSN: 0733-950X.

Chang, H.H. (2006a). Generalized computer program: FLUVIAL-12 Mathematical Model for Erodible Channel Users Manual. San Deigo State University, San Deigo, California.

Chang, C.K., Ab. Ghani, A., Zakaria, N.A., \& Abdullah, R. (2005). Sediment Transport in Kulim River, Malaysia. In: Proceedings of XXXI IAHR Congress: Water Engineering for the Future - Choice and Challenges, September, 2005. Seoul, Korea, pp. 11541162, ISBN: 89-87898-24-5.

Chang, C.K. (2006b). Sediment Transport in Kulim River, Kedah. M.Sc. Thesis. Universiti Sains Malaysia. Penang.

Chang, C.K., Ab. Ghani, A., Abdullah, R., Zakaria, N.A. (2008). Sediment transport modeling for Kulim River : a case study. eburnal of Hydroenvironment Research, Vol. 2, No. 1, 47-59. IAHR \& KWRA. ISSN: 1570-6443.

Department of Irrigation and Drainage Malaysia or DID. (1976). River Discharge Measurement by Current Meter - Hydrological Procedure No. 15. DID, Kuala Lumpur.

Department of Irrigation and Drainage Malaysia or DID. (1977). The Determination of Suspended Sediment Discharge - Hydrological Procedure No. 19. DD, Kuala Lumpur. 
Department of Irrigation and Drainage Malaysia. (1996). Study on Flood Mitigation and Drainage Master Plan for Kulim and its Surroundings. Final Report. DID, Kedah Darul Aman.

Department of Irrigation and Drainage Malaysia or DID. (2009). Study on River Sand Mining Capacity in Malaysia. DID, Kuala Lumpur.

Department of Water Resources or DWR (2004). Effects of Project Operations on Geomorphic Processes Downstream of Oroville Dam: Task 7 - Hydraulic and Sediment Transport Modeling With FLUVIAL-12. Draft Final Report. Oroville Facilities Relicensing FERC Project No. 2100, The Resources Agency, State of California.

Edwards, T.K. Glysson, G.D. (1999). Field Methods for Measurement of Fluvial Sediment. U.S. Geological Survey Techniques of Water-Resources Investigations. Book, Chapter C2.

Fan, S.S. (1988). Twelve Selected Computer Stream Sedimentation Models Developed in the United State. In: Proceeding of the Interagency Symposium on Computer Stream Sedimentation Model, Denver, Colorado. Published by the Federal Energy Regulatory Commission, Washington, DC.

Federal Interagency Stream Restoration Working Group or FISRWG. (2001). Stream Corridor Restoration: Principles, Processes, and Practices. Federal Interagency Stream Restoration Working Group (15 Federal agencies of the US Government), Portland. ISBN: 0-934213-59-3.

Lagasse, P.F., Schall, J.D., Richardson, E.V. (2001). Stream Stability at Highway Structures, US Department of Transportation, Federal Highway Administration. Publication No. FHWA NHI 01-002 (Hydraulic Engineering Circular No. 20), 3rd Edition, Washington, D.C.

Majlis Daerah Kulim or MDK (1993). Kulim Structure Plan, 1990-2010. Kuala Lumpur.

National Research Council. (1983). An Evaluation of Flood-level Prediction using Alluvial River Model. National Academy Press, Washington, D.C

Richardson, E.V., Simons, D.B., Lagasse, P.F., (2001). River Engineering for Highway Encroachments - Highways in The River Enviroment, US Department of Transportation, Federal Highway Administration. Publication No. FHWA NHI 01004 (Hydraulic Design Series Number 6), Washington, D.C.

Sirdari, Z.Z. (2009). Effects of Channelization on the Stability of Kulim River. M.Sc. Thesis. Universiti Sains Malaysia. Penang.

United States Army Corps of Engineers or USACE (1995). Sedimentation Investigations of Rivers and Reservoirs. USACE Engineering and Design Manual. Publication No. EM 1110-2-4000, Washington, D.C.

Yuqian, L. (1989). Manual on Operational Methods for the Measurement of Sediment Transport. Operational Hydrology Report No. 29, World Meteorological Organisation, Geneva, Switzerland, 169 p. ISBN: 92-63-10686-X. 


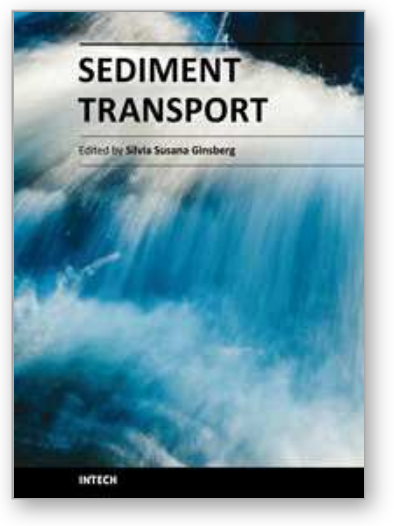

\author{
Sediment Transport \\ Edited by Dr. Silvia Susana Ginsberg
}

ISBN 978-953-307-189-3

Hard cover, 334 pages

Publisher InTech

Published online 26, April, 2011

Published in print edition April, 2011

Sediment transport is a book that covers a wide variety of subject matters. It combines the personal and professional experience of the authors on solid particles transport and related problems, whose expertise is focused in aqueous systems and in laboratory flumes. This includes a series of chapters on hydrodynamics and their relationship with sediment transport and morphological development. The different contributions deal with issues such as the sediment transport modeling; sediment dynamics in stream confluence or river diversion, in meandering channels, at interconnected tidal channels system; changes in sediment transport under fine materials, cohesive materials and ice cover; environmental remediation of contaminated fine sediments. This is an invaluable interdisciplinary textbook and an important contribution to the sediment transport field. I strongly recommend this textbook to those in charge of conducting research on engineering issues or wishing to deal with equally important scientific problems.

\title{
How to reference
}

In order to correctly reference this scholarly work, feel free to copy and paste the following:

Chun Kiat, Chang and Aminuddin, Ab. Ghani (2011). Sediment Transport in Kulim River, Kedah, Malaysia, Sediment Transport, Dr. Silvia Susana Ginsberg (Ed.), ISBN: 978-953-307-189-3, InTech, Available from: http://www.intechopen.com/books/sediment-transport/sediment-transport-in-kulim-river-kedah-malaysia

\section{INTECH}

open science | open minds

\author{
InTech Europe \\ University Campus STeP Ri \\ Slavka Krautzeka 83/A \\ 51000 Rijeka, Croatia \\ Phone: +385 (51) 770447 \\ Fax: +385 (51) 686166 \\ www.intechopen.com
}

\author{
InTech China \\ Unit 405, Office Block, Hotel Equatorial Shanghai \\ No.65, Yan An Road (West), Shanghai, 200040, China \\ 中国上海市延安西路65号上海国际贵都大饭店办公楼405单元 \\ Phone: +86-21-62489820 \\ Fax: $+86-21-62489821$
}


(C) 2011 The Author(s). Licensee IntechOpen. This chapter is distributed under the terms of the Creative Commons Attribution-NonCommercialShareAlike-3.0 License, which permits use, distribution and reproduction for non-commercial purposes, provided the original is properly cited and derivative works building on this content are distributed under the same license. 